\section{Evaluation of Winter Squash and Pumpkin Cultivars for Age-related Resistance to Phytophthora capsici Fruit Rot}

\author{
Charles S. Krasnow and Mary K. Hausbeck ${ }^{1}$ \\ Department of Plant, Soil, and Microbial Sciences, Michigan State \\ University, East Lansing, MI 48824
}

Additional index words. ontogenetic, pepo, oomycete, Cucurbita

\begin{abstract}
Phytophthora capsici annually threatens production of cucurbit and solanaceous crops. Long-lived oospores produced by the pathogen incite primary infection of susceptible plants when conditions are wet. Limiting the rot of winter squash and pumpkin (Cucurbita sp.) fruits is difficult due to the long maturation period when fruits are often in direct contact with infested soil. Genetic resistance to fruit rot is not widely available within Cucurbita sp.; however, age-related resistance (ARR) to $P$. capsici fruit rot develops in specific cultivars during maturation. The objective of this study was to evaluate the fruits of 12 cultivars of Cucurbita pepo, Cucurbita moschata, and Cucurbita maxima for ARR to $P$. capsici using a mycelial-plug inoculation method. All Cucurbita pepo and Cucurbita moschata cultivars displayed ARR; 7 days postpollination (dpp) fruits were susceptible, limited lesion development occurred on fruits $22 \mathrm{dpp}$, and lesions did not develop at $56 \mathrm{dpp}$. Disease developed on both Cucurbita maxima cultivars tested at 7, 14, 22, and 56 dpp. Firmness of fruit exocarps was measured with a manual penetrometer. Exocarp firmness of all cultivars increased during maturation; however, there was no correlation between firmness and disease incidence among cultivars at 22 dpp $\left(R^{2}=-0.01, P=0.85\right)$. When fruits of cultivars expressing ARR at $22 \mathrm{dpp}$ were wounded before inoculation, fruit rot developed.
\end{abstract}

Phytophthora capsici is a destructive pathogen of cucurbit and solanaceous vegetables. All cultivars of squash are considered susceptible to phytophthora root, crown, and fruit rot (Babadoost and Islam, 2003; Cafe et al., 1995); losses in winter squash and pumpkin (Cucurbita sp.) production have exceeded 50\% (Babadoost, 2000; Isakeit, 2007; Meyer and Hausbeck, 2013a). The pathogen overwinters in the soil and plant residue as long-lived oospores that serve as primary inoculum. The polycyclic production of sporangia and zoospores occurs on infected plant tissue. Movement of $P$. capsici in surface water used for irrigation has contributed to the dispersal of the pathogen in Michigan (Gevens et al., 2007). Managing phytophthora root and crown rot requires an integrated approach that includes raised plant beds in conjunction with fungicides applied via drip irrigation or soildirected sprays (Foster and Hausbeck, 2010; Jones and McGovern, 1994; Meyer and

Received for publication 13 July 2016. Accepted for publication 18 Aug. 2016.

We thank Sheila Linderman and Alex Cook for technical assistance.

This research was supported by funding from Michigan Specialty Crop Block Grant No. 791 N13200129 awarded to the Michigan Vegetable Council.

${ }^{1}$ Corresponding author. E-mail: hausbec1@msu. edu.
Hausbeck, 2013b). Tolerance to root rot has been identified in cultivars of summer (Cucurbita pepo) and winter squash (Cucurbita moschata) and cucumber (Cucumis sativus) (Hausbeck and Lamour, 2004; Meyer and Hausbeck, 2012; Ppoyil, 2011). Raised bed culture with plastic mulch-covered plant beds can limit soil splash onto fruit (Kousik et al., 2011); however, vines of winter squash and pumpkin typically grow off of the plastic mulch coming into direct contact with the soil between the plants beds. Foliar fungicides to protect against fruit rot are limited by a dense foliar canopy and an inability to cover the fruit surface in contact with the soil (Newhall and Wilkinson, 1949). Additionally, raised plant beds covered with plastic mulch with trickle irrigation are not economical for growers of winter squash for processing where profit margins are narrow. Over 40,000 acres of winter squash and pumpkin grown in the Midwest (Anonymous, 2015) highlight the importance of developing effective strategies to limit fruit rot.

The ability of plants to acquire resistance to pathogens as they mature has been studied in many host-pathogen systems (Gadoury et al., 2003; Gerlach et al., 1976; Kennelly et al., 2005; Kim et al., 1989), especially resistance of seedlings to oomycete pathogens (Koh et al., 1987; Lazarovits et al., 1981; McClure and Robbins, 1942; Mellano et al., 1970). Vegetable crops in the Cucurbitaceae and Solanaceae families develop ARR to $P$. capsici fruit rot (Ando et al., 2009; Biles et al., 1993; Gevens et al., 2006; Meyer and Hausbeck, 2013a) and modifications to disease management programs have been suggested (Ando et al., 2009; Hausbeck and Lamour, 2004; Krasnow et al., 2014; Meyer and Hausbeck, 2013a). The fruits of cucurbit crops including acorn squash, pumpkin, and cucumber are highly susceptible to $P$. capsici during early fruit formation, but become increasingly resistant as they mature (Ando et al., 2009; Gevens et al., 2006). Watermelon, muskmelon, and summer squash do not appear to have appreciable levels of resistance (Ando et al., 2009). Meyer and Hausbeck (2013a) found differences in the onset and magnitude of ARR to P. capsici fruit rot between 'Dickenson Field' (Cucurbita moschata) and 'Golden Delicious' (Cucurbita maxima) processing squashes. Although both cultivars were susceptible to the pathogen up to $14 \mathrm{dpp}$, 'Dickenson Field' developed $\mathrm{ARR}$ at $21 \mathrm{dpp}(<15 \%$ fruit rot $)$, whereas 'Golden Delicious' remained susceptible $(\approx 80 \%$ fruit rot). Mechanical harvesting of processing squash with incipient
Table 1. Cultivars, market use, and days to maturity of winter squash and pumpkin evaluated for agerelated resistance to Phytophthora capsici fruit rot.

\begin{tabular}{lllr}
\hline Cucurbita species & \multicolumn{1}{c}{ Cultivar } & Intended use & Days to maturity \\
\hline C. pepo & & & \\
Acorn squash & Autumn Delight & \\
Acorn squash & Table Ace $^{\mathrm{z}}$ & Fresh market & 90 \\
Acorn squash & Table Gold $^{\mathrm{z}}$ & Fresh market & 70 \\
Pie pumpkin & Chucky $^{\mathrm{z}}$ & Fresh market & 80 \\
Pumpkin & Diablo $^{\mathrm{z}}$ & Fresh market & 85 \\
Mini-pumpkin & Gold Dust $^{\mathrm{z}}$ & Ornamental & 100 \\
Spaghetti squash & Vegetable Spaghetti $^{\mathrm{z}}$ & Ornamental & 95 \\
C. moschata & & Fresh market & 100 \\
Butternut squash & Avalon $^{\mathrm{y}}$ & Fresh $/$ processing & \\
& & market & 90 \\
Butternut squash & Early Butternut $^{\mathrm{z}}$ & Fresh market & 82 \\
Butternut squash & Waltham Butternut $^{\mathrm{z}}$ & Fresh market & 110 \\
C. maxima & & & \\
Hubbard squash & Hubba Hubba $^{\mathrm{x}}$ & Fresh market & 95 \\
Pumpkin & Lumina $^{\mathrm{y}}$ & Ornamental & 100 \\
\hline
\end{tabular}

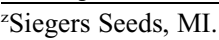

${ }^{\text {ySeedway, PA. }}$

‘Johnny's Selected Seeds, ME. 
P. capsici infections can result in spread of the pathogen to surrounding fruit postharvest and during transportation, resulting in potential loss of entire truckloads (Hausbeck and Lamour, 2004; Kousik et al., 2014). The large acreage and low profit margin of squash grown for the processing market necessitate novel methods of disease control.

The differences in the onset of ARR among cucurbits (Ando et al., 2009; Gevens et al., 2006; Krasnow and Hausbeck, 2015) and the lack of ARR in cultivars of watermelon (Citrullus lanatus) and winter squash (Cucurbita maxima) (Kousik et al., 2012; Krasnow and Hausbeck, 2015; Meyer and Hausbeck, 2013a) have made it difficult to incorporate this feature into disease management programs. Fungicides are applied to pickling cucumbers during the period of rapid fruit growth when the fruit are highly susceptible to $P$. capsici (Hausbeck and Lamour, 2004). Identifying winter squash and pumpkin cultivars that express ARR could help growers make cultivar selections and time fungicide applications to protect developing fruit. The objectives of this study

Table 2. Exocarp firmness during development of select winter squash and pumpkin cultivars.

\begin{tabular}{lccrc}
\hline & \multicolumn{4}{c}{ Exocarp firmness $(\mathrm{kg})^{\mathrm{z}}$} \\
\cline { 2 - 5 } Cultivar & \multicolumn{4}{c}{ Days postpollination } \\
\cline { 2 - 5 } & 7 & \multicolumn{1}{c}{22} & 56 \\
\hline Autumn Delight & 3.6 & 5.5 & 10.2 & 12.8 \\
Chucky & 3.3 & 6.3 & 10.0 & 12.3 \\
Diablo & 3.3 & 4.1 & 8.0 & 11.1 \\
Gold Dust & 3.1 & 8.2 & 12.7 & 13.0 \\
Table Ace & 3.2 & 7.9 & 11.9 & 13.0 \\
Table Gold & 3.8 & 7.2 & 11.1 & 12.5 \\
Vegetable Spaghetti & 2.7 & 5.2 & 10.0 & 12.7 \\
Avalon & 3.6 & 5.8 & 8.5 & 12.3 \\
Early Butternut & 3.1 & 5.9 & 9.0 & 11.6 \\
Waltham Butternut & 3.5 & 6.4 & 9.1 & 11.8 \\
Hubba Hubba & 3.4 & 5.0 & 7.2 & 10.1 \\
Lumina & 2.8 & 4.8 & 6.0 & 11.7 \\
\hline
\end{tabular}

${ }^{\mathrm{z}}$ Measurement made using a model FT 327 fruit penetrometer with 5-mm plunger. Value represents pressure $(\mathrm{kg})$ required to puncture fruit surface. were to 1) evaluate winter squash and pumpkin cultivars (Cucurbita sp.) for ARR to $P$. capsici and 2) determine the effect of morphophysiological changes during winter squash and pumpkin fruit development on ARR. A brief report of this work has been published (Krasnow and Hausbeck, 2015).

\section{Materials and Methods}

Plant culture and fruit inoculation. Twelve winter squash and pumpkin cultivars representing the three most economically important Cucurbita sp. were selected (Table 1). Seeds were planted into 72-cell flats containing soilless media (Suremix Michigan Grower Products Inc., Galesburg, MI) and grown for 3 weeks in a greenhouse with $27{ }^{\circ} \mathrm{C}$ day $/ 25{ }^{\circ} \mathrm{C}$ night temperatures. Squash and pumpkin seedlings were transplanted into $15-\mathrm{cm}$ raised plant beds covered with black polyethylene plastic at the Michigan State University Plant Pathology Farm in Lansing, MI. The soil type was a Capac loam that was previously cropped to pumpkin and had no history of $P$. capsici infestation. Watering was accomplished with trickle irrigation and plants were grown according to local commercial production standards for fertilizer and pest management (Bird et al., 2014). Once female flowers reached anthesis, male flowers were removed and used to pollinate female flowers of the same cultivar. Female flowers were tagged with the date of pollination and desired harvest age. Fruit were harvested 7, 14, 22, and $56 \mathrm{dpp}$, ages were selected based on developmental changes in fruit color, firmness, and size (Loy, 2004; Meyer and Hausbeck, 2013a). Following harvest, fruit were surface sterilized in $10 \%$ bleach for 5 min, rinsed with tap water, and air-dried on a laboratory bench. Fruit length from the apex to blossom end and the width at the fruit's widest point were measured. Two $P$. capsici isolates obtained from the culture collection of M. Hausbeck at Michigan State University, East Lansing, MI,

Table 3. Growth rating and disease incidence $4 \mathrm{~d}$ after inoculation with Phytophthora capsici of winter squash and pumpkin cultivars 7,14 , and $22 \mathrm{~d}$ postpollination.

\begin{tabular}{llllrrr}
\hline & \multicolumn{5}{c}{ P. capsici growth rating $^{\mathrm{z}}$} & \multicolumn{3}{c}{ Days postpollination } \\
\cline { 2 - 7 } Cultivar & \multicolumn{7}{c}{ Infed fruit (\%) } \\
\cline { 2 - 7 } Autumn & $3.4^{\mathrm{y}}$ & 1.5 & $0.2 \mathrm{~d}^{\mathrm{x}}$ & 94 & 43 & 22 \\
Chucky & 3.1 & 2.7 & $2.3 \mathrm{a}$ & 76 & 75 & 75 \\
Diablo & 3.6 & 2.1 & $0.4 \mathrm{~cd}$ & 94 & 63 & 19 \\
Gold Dust & 3.8 & 3.3 & $1.1 \mathrm{~b}$ & 94 & 100 & 63 \\
Table Ace & 3.1 & 2.6 & $0.2 \mathrm{~d}$ & 81 & 81 & 6 \\
Table Gold & 3.6 & 2.5 & $0.4 \mathrm{bcd}$ & 94 & 69 & 25 \\
Vegetable Spaghetti & 2.7 & 1.3 & $0.0 \mathrm{~d}$ & 69 & 50 & 0 \\
Avalon & 3.6 & 1.4 & $0.2 \mathrm{~d}$ & 94 & 75 & 19 \\
Early Butternut & 3.8 & 1.3 & $0.2 \mathrm{~d}$ & 94 & 56 & 19 \\
Waltham Butternut & 3.6 & 1.7 & $0.4 \mathrm{bcd}$ & 100 & 88 & 44 \\
Hubba Hubba & 3.5 & 2.7 & $0.9 \mathrm{bc}$ & 88 & 75 & 31 \\
Lumina & 4.0 & 2.9 & $0.9 \mathrm{bc}$ & 100 & 94 & 56 \\
\hline
\end{tabular}

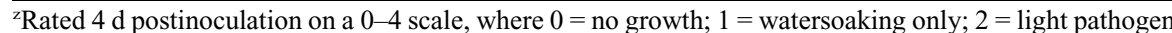
growth; 3 = moderate pathogen growth; $4=$ dense pathogen growth. Values represent the mean of two experiments with 8 fruit per age.

${ }^{y}$ Column means for $P$. capsici growth rating without a letter are not significantly different $(P=0.05)$.

${ }^{\mathrm{x}}$ Column means with a common letter are not significantly different based on Fisher's least significant difference test $(P=0.05)$. were used for fruit inoculation; OP97 (A1 mating type, sensitive to mefenoxam, isolated from pumpkin) and 12889 (A1 mating type, insensitive to mefenoxam, isolated from pepper). The isolates were grown on V8 juice agar ( $143 \mathrm{~mL}$ V8 juice, $3 \mathrm{~g} \mathrm{CaCO}_{3}$, $16 \mathrm{~g}$ agar/L). To ensure isolate virulence, the isolates were used to inoculate squash fruit and subsequently recovered from the diseased fruit before the initiation of the study (Quesada-Ocampo and Hausbeck, 2010). To inoculate fruit, a 7-mm agar plug from the margin of an actively growing colony was placed mycelial side down in the middle of each fruit on the unwounded fruit surface. The agar plug was covered with a sterile plastic screw cap (Axygen Inc., Union City, CA) using petroleum jelly as a fixative to prevent plug desiccation. Control fruit were inoculated with sterile V8-agar plugs. Isolate OP97 was not used to inoculate 56 dpp fruit as there was not an adequate supply of the large-fruited Cucurbita sp. The inoculated fruit were incubated in large clear plastic bins (Sterilite, Townsend, MA) lined with moist paper towel to maintain high relative humidity $(\mathrm{RH})$. WatchDog Dataloggers (Spectrum Technologies, Inc., Aurora, IL) were used to monitor temperature and $\mathrm{RH}$ within the bins. The average temperature and $\mathrm{RH}$ were $24.0{ }^{\circ} \mathrm{C}$ and $99.7 \%$, respectively, during the study.

Fruit were removed from the bins $4 \mathrm{~d}$ postinoculation and lesion diameter was measured on two axes. Pathogen growth and sporulation were rated on a 0 to 4 scale adapted from Meyer and Hausbeck (2013a) where $0=$ no visible pathogen growth; $1=$ water-soaking only; 2 = light visible mycelial growth; $3=$ moderate mycelial growth; and $4=$ dense mycelial growth. Fruit receiving a mean rating value $\leq 0.5$ were considered resistant $(R)$, and fruit with a mean rating value $>0.5$ but $<1.5$ were considered intermediately resistant (IR). After disease assessment, 1- to 2-mm tissue sections were removed from the margin of diseased tissue and plated onto BARP (50 ppm benomyl, 100 ppm ampicillin, $30 \mathrm{ppm}$ rifampicin, and $100 \mathrm{ppm}$ pentachloronitrobenzene)-amended V8 agar plates. Recovered isolates were confirmed as $P$. capsici by pathogen morphology on V8-agar (Waterhouse, 1963). Mefenoxam sensitivity (Lamour and Hausbeck, 2000) was determined to verify similarity to the isolate used for inoculation. Control fruit were observed for symptoms and tissue samples cultured to confirm the absence of $P$. capsici infection. There were four fruit per replication per isolate with one control. The experiment was conducted twice.

Fruit firmness testing and wound assay. Pericarp and exocarp firmness of healthy fruits were measured using a fruit penetrometer (model FT 327; QA Supplies LLC, Norfolk, VA) with a 5-mm-diameter press. The measurement was taken from squash or pumpkin tissue $\left(\approx 25 \mathrm{~cm}^{2}\right)$ after rating pathogen growth. Exocarp firmness was measured by using the fruit penetrometer to directly penetrate the exocarp. Pericarp tissue 
firmness was measured by removing the exocarp (0.5- to $1.0-\mathrm{mm}$ depth) with a sterile scalpel before the measurement. For the wound assay, 22 dpp fruit from five cultivars representing each Cucurbita sp. were selected. Each fruit was wounded with a sterile needle to $1-\mathrm{cm}$ depth before inoculation, and then incubated and assessed for disease as described previously. Isolate 12889 was used to inoculate fruit for the wound assay.

Data analysis. Data analysis was accomplished using SAS v9.3 (SAS Institute, Cary, NC). Differences among the variables including pathogen growth rating, lesion size, exoand pericarp firmness, and fruit age were analyzed using analysis of variance in SAS Proc Mixed. Mean differences were separated using Fisher's least significant difference $(P=0.05)$. Correlations among morphological features and disease incidence and severity at the four selected ages were analyzed with Pearson's correlation coefficient $(P=0.05)$. Homogeneity of variance between isolates was assessed by residual analysis and data from each isolate were pooled as there were no significant differences in pathogen growth rating, lesion size, and disease incidence. Control fruit did not display symptoms after inoculation with sterile agar and were not included in the analyses.

\section{Results}

The fruits of all winter squash and pumpkin cultivars tested increased in size and exoand pericarp firmness as they matured from 7 to $56 \mathrm{dpp}$ (Table 2). From 14 to $21 \mathrm{dpp}$, fruits increased in width for 'Diablo' (47\%), 'Hubba Hubba' (25\%), 'Lumina' (19\%), and 'Vegetable Spaghetti' (14\%); fruits from all other cultivars increased $<5 \%$. The length of fruits of all cultivars increased $<15 \%$ from 14 to 21 dpp, with the exception of 'Diablo' (29\%) (data not shown). At 22 dpp, 'Hubba Hubba' and 'Lumina' (Cucurbita maxima) had the least firm exocarp, whereas 'Gold Dust' and 'Table Ace' (Cucurbita pepo) had the firmest exocarp (Table 2). There was no correlation between exocarp firmness and disease incidence among cultivars at $22 \mathrm{dpp}(r=$ $-0.01 ; P=0.85)$. Exo- and pericarp firmness was negatively correlated with disease incidence and pathogen growth when analyzed across all ages tested $(r=-0.53 ; P<0.0001)$. The exocarp of 'Table Ace' and 'Gold Dust' were the firmest among the cultivars tested at 14, 22, and 56 dpp (Table 2).

All cultivars were susceptible to $P$. capsici at $7 \mathrm{dpp}$ with fruit rot incidence ranging from $69 \%$ to $100 \%$ (Table 3); pathogen growth was similar among cultivars $(P=0.241)$. 'Vegetable Spaghetti', 'Avalon', 'Early', and 'Waltham' were IR at $14 \mathrm{dpp}$ with an average growth rating $<1.5$ (Table 3 ). 'Autumn Delight' and 'Vegetable Spaghetti' had the lowest disease incidence at this age (50\%; Table 3). At $22 \mathrm{dpp}$, average disease ratings for all but two cultivars were $<1$ (Table 3 ) and disease incidence was $>20 \%$ for six cultivars. Fruits from the two Cucurbita maxima cultivars Lumina and
Hubba Hubba were the only ones to become infected at $56 \mathrm{dpp}$, with $63 \%$ and $25 \%$ fruit rot, respectively (data not shown).

Wounding the fruits of five cultivars before inoculation significantly increased disease incidence and pathogen growth $(P \leq 0.0001)$ compared with the unwounded inoculated fruits. 'Vegetable Spaghetti' had an average growth rating of $<1$ after wound inoculation due to a lack of pathogen sporulation and mycelial growth (Fig. 1); however, average lesion size was $4.1 \mathrm{~cm}$, with $88 \%$ fruit rot incidence (Fig. 2). 'Table Ace', 'Gold Dust', 'Waltham', and 'Hubba Hubba' exhibited $100 \%$ fruit infection following inoculation of the wounded fruits, with an average rating of 3.0, 2.5, 3.5, and 3.6, respectively (Fig. 2). Superficial wounding of 'Table Ace' fruit by removing a thin piece of the exocarp $<1.0 \mathrm{~mm}$ thick with a scalpel before inoculation resulted in $100 \%$ infection (data not shown).

\section{Discussion}

The relatively long maturation time and growth habit of winter squash and pumpkin increases the risk of phytophthora fruit rot in growing regions with frequent rainfall and infested soil. Representative

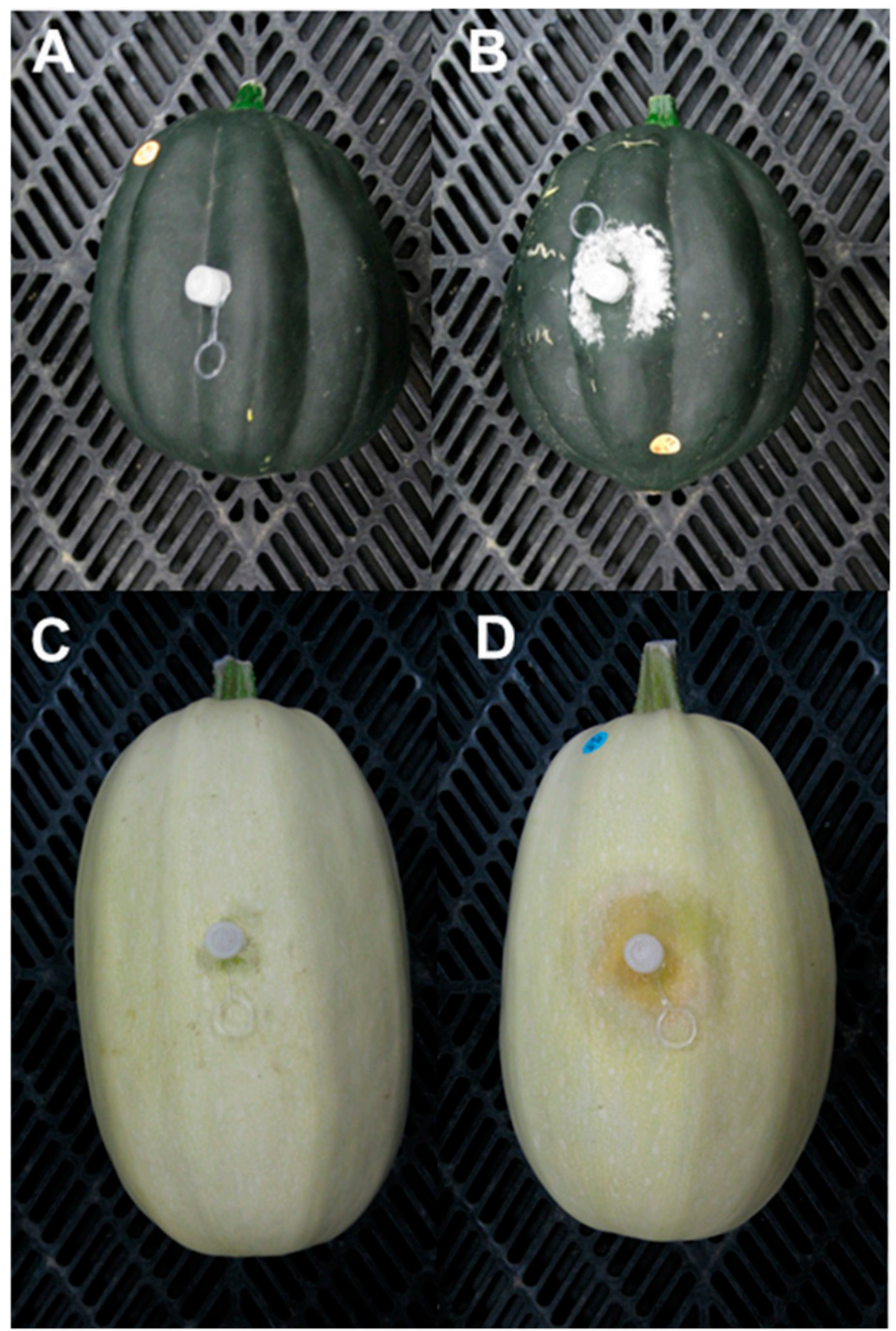

Fig. 1. Effect of Phytophthora capsici inoculation on (A, C) unwounded and (B, D) puncture wounded fruits of $(\mathbf{A}, \mathbf{B})$ 'Table Ace' and $(\mathbf{C}, \mathbf{D})$ 'Vegetable Spaghetti' $4 \mathrm{~d}$ postinoculation. Note the lack of sporulation on diseased tissue in (D). 

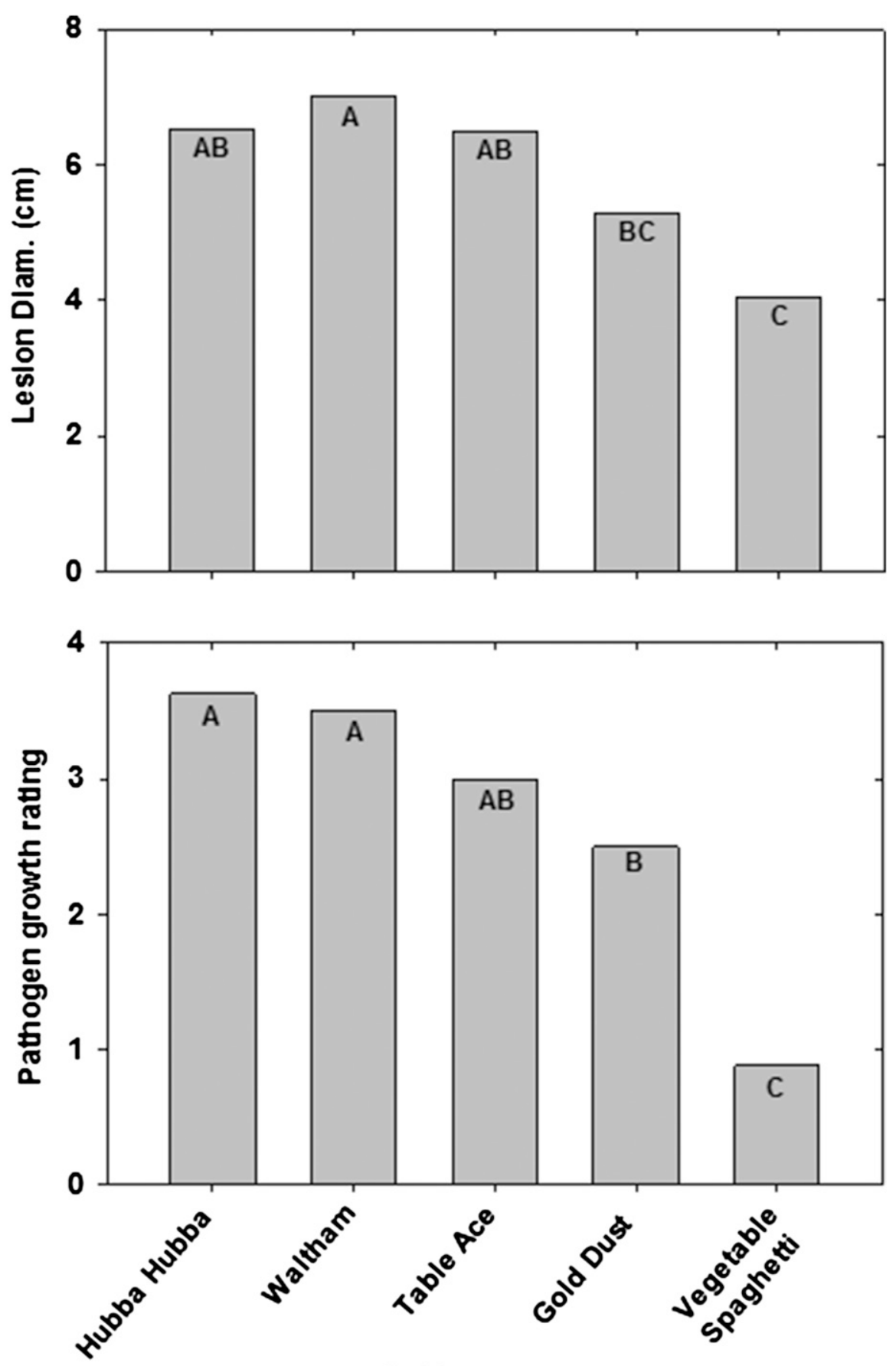

\section{Cultivar}

Fig. 2. Lesion diameter and pathogen growth rating $4 \mathrm{~d}$ postinoculation with Phytophthora capsici of $22 \mathrm{~d}$ postpollination puncture wounded winter squash and pumpkin fruits. Fruits were wounded with a sterile needle to 1-cm depth before inoculation. Each bar represents the mean of two trials with four replicate fruits per isolate per trial. Bars with a letter in common are not significantly different based on Fisher's least significant difference $(P<0.05)$.

cultivar types of Cucurbita pepo, Cucurbita moschata, and Cucurbita maxima include jack-o-lantern pumpkin, butternut squash, spaghetti squash, and processing squash and all are susceptible to $P$. capsici fruit rot (Babadoost, 2000; Isakeit, 2007; McGrath, 2000; Meyer and Hausbeck, 2013a). Cultural practices including trellising and choosing varieties with a compact plant size can help prevent $P$. capsici fruit rot by avoiding contact with infested soil (Ando and with this period of growth (Krasnow and Hausbeck, 2015; Meyer and Hausbeck, 2013a). Similar to the results of experiments by Meyer and Hausbeck (2013a), the fruits of Cucurbita maxima cultivars in this study displayed a greater incidence of infection than the fruits of Cucurbita pepo and Cucurbita moschata cultivars. The Cucurbita maxima cultivars were the only Cucurbita sp. to develop $P$. capsici lesions at $56 \mathrm{dpp}$. Exocarp firmness of 'Golden Delicious' (Cucurbita maxima) and 'Dickenson Field' (Cucurbita moschata) processing squashes increased as the fruit matured, but firmness was not correlated with $P$. capsici lesion size on Golden Delicious, a cultivar highly susceptible to fruit rot (Meyer and Hausbeck, 2013a). In this study, there was no correlation between exocarp firmness and disease incidence among winter squash and pumpkin cultivars $22 \mathrm{dpp}$. Changes in surface wax as cucurbit fruit develop have been implicated as influencing resistance to $P$. capsici (Ando et al., 2009). Cucurbita maxima begins to accumulate epicuticular wax at 14 dpp (Sutherland and Hallett, 1993). Watermelon fruit also develop a thick wax layer at $14 \mathrm{dpp}$, which covers the fruit surface and stomat (Frankle and Hopkins, 1993). Fruits of Cucurbita maxima and Citrullus lanatus cultivars are susceptible to $P$. capsici at all maturity stages (Kousik et al., 2012; Krasnow and Hausbeck, 2015; Meyer and Hausbeck, 2013a), and changes in surface wax likely have a limited effect on ARR and fruit rot. Recent studies have identified Cucurbita pepo and Citrullus lanatus germplasm accessions with resistance to $P$. capsici fruit rot as early as $7 \mathrm{dpp}$ during the period of fruit elongation (Kousik et al., 2012; Krasnow et al., 2014) providing additional evidence for the limited role of surface wax in resistance to fruit rot.

Biles et al. (1993) found that the cuticle of pepper increased in thickness as the fruit matured from green to red and developed resistance to $P$. capsici fruit rot. Similarly, the thicker cuticle and epidermal cells of the stem end of tomato were suggested to prevent infection of the fruit by P. capsici (Simonds and Kreutzer, 1944). The stylar end did not possess these characteristics and infection occurred within 70 to $90 \mathrm{~min}$ after inoculation. The exocarp of cucurbit fruit is likely the location where ARR is expressed as wounding the fruit before inoculation negates ARR. The surface of Cucurbita sp. contains trichomes and stomata (Barber, 1909; Sutherland and Hallett, 1993) and differences in the quantity and morphology of these structures may influence ARR to P. capsici. Zoospores were observed to accumulate preferentially over stomata of a Cucurbita maxima cultivar susceptible to $P$. capsici, but not a Cucurbita moschata cultivar with ARR (C. Krasnow and M. Hausbeck, unpublished data). Microcracks in the fruits surface also occur due to growth and water influx (Schaffer and Boyer, 1984) and may influence the susceptibility of winter squash and pumpkin cultivars to fruit rot. 
Phytophthora fruit rot has long been a limiting factor in winter squash and pumpkin production. Cultivars that express ARR to $P$. capsici as early as $14 \mathrm{dpp}$ could be selected as part of an integrated management program with fungicide sprays timed for the onset of fruit formation when protection is most needed. Winter squash and pumpkin may be stored postharvest before transporting and marketing. Infection and disease development of the fruit during postharvest storage are especially costly to growers due to the added expenses associated with disposing of the rotted produce. The use of cucurbit cultivars that express ARR may limit postharvest losses since ARR decreases the risk of fruit rot developing as the crop reaches maturity.

\section{Literature Cited}

Ando, K. and R. Grumet. 2006. Evaluation of altered cucumber plant architecture as a means to reduce Phytophthora capsici disease incidence on cucumber fruit. J. Amer. Soc. Hort. Sci. 131:491-498.

Ando, K., S. Hammar, and R. Grumet. 2009. Agerelated resistance of diverse cucurbit fruit to infection by Phytophthora capsici. J. Amer. Soc. Hort. Sci. 134:176-182.

Anonymous. 2015. Vegetables summary 2015. U.S. Dep. Agr. Nat. Agric. Stat. Serv. 5 Feb. 2016 $<$ http://usda.mannlib.cornell.edu/usda/current/ VegeSumm/VegeSumm-02-04-2016.pdf>.

Babadoost, M. 2000. Outbreak of Phytophthora foliar blight and fruit rot in processing pumpkin fields in Illinois. Plant Dis. 84:1345.

Babadoost, M. and S.Z. Islam. 2003. Fungicide seed treatment effects on seedling damping-off of pumpkin caused by Phytophthora capsici. Plant Dis. 87:63-68.

Barber, K.G. 1909. Comparative histology of fruits and seeds of certain species of Cucurbitaceae. Bot. Gaz. 47:263-310.

Biles, C.L., M.M. Wall, M. Waugh, and H. Palmer. 1993. Relationship of Phytophthora fruit rot to fruit maturation and cuticle thickness of New Mexican-type peppers. Phytopathology 83:607-611.

Bird, G., H. Hausbeck, L. Jess, W. Kirk, Z. Szendrei, and F. Warner. 2014. Insect, disease and nematode control for commercial vegetables. Michigan State University Ext. Bull. E-312.

Cafe, A.C., J.M. Duniway, and R.M. Davis. 1995. Effects of the frequency of furrow irrigation on root and fruit rots of squash caused by Phytophthora capsici. Plant Dis. 79:44-48.

Foster, J.M. and M.K. Hausbeck. 2010. Managing Phytophthora crown and root rot in bell pepper using fungicides and host resistance. Plant Dis. 94:697-702.

Frankle, W. and D. Hopkins. 1993. Ingress of the watermelon fruit blotch bacterium into fruit. Plant Dis. 77:1090-1092.
Gadoury, D.M., R.C. Seem, A. Ficke, and W.F. Wilcox. 2003. Ontogenic resistance to powdery mildew in grape berries. Phytopathology 93:547-555.

Gerlach, W.W.P., H.A.J. Hoitink, and A.F. Schmitthenner. 1976. Phytophthora citrophthora on Pieris japonica: Infection, sporulation, and dissemination. Phytopathology 66:302-308.

Gevens, A.J., K. Ando, K.H. Lamour, R. Grumet, and M.K. Hausbeck. 2006. A detached cucumber fruit method to screen for resistance to Phytophthora capsici and effect of fruit age on susceptibility to infection. Plant Dis. 90:12761282.

Gevens, A.J., R.S. Donahoo, K.H. Lamour, and M.K. Hausbeck. 2007. Characterization of Phytophthora capsici from Michigan surface irrigation water. Phytopathology 97:421-428.

Hausbeck, M.K. and K.H. Lamour. 2004. Phytophthora capsici on vegetable crops: Research progress and management challenges. Plant Dis. 88:1292-1303.

Isakeit, T. 2007. Phytophthora blight caused by Phytophthora capsici on pumpkin and winter squash in Texas. Plant Dis. 91:633.

Jones, J.P. and R.J. McGovern. 1994. Effect of temperature and fungicides on the development of Phytophthora blight and fruit rot of squash. Proc. Fla. State Hort. Soc. 107:147-150.

Kennelly, M.M., D.M. Gadoury, W.F. Wilcox, P.A. Magarey, and R.C. Seem. 2005. Seasonal development of ontogenic resistance to downy mildew in grape berries and rachises. Phytopathology 95:1445-1452.

Kim, Y.J., B.K. Hwang, and K.W. Park. 1989. Expression of age-related resistance in pepper plants infected with Phytophthora capsici. Plant Dis. 73:745-747.

Koh, Y.J., B.K. Hwang, and H.S. Chung. 1987. Adult-plant resistance of rice to leaf blast. Phytopathology 77:232-236.

Kousik, C., J. Ikerd, and H. Harrison. 2014. Pre-and post-harvest development of Phytophthora fruit rot on watermelons treated with fungicides in the field. Plant Health Prog. 15:145-150.

Kousik, C., J. Ikerd, P. Wechter, H. Harrison, and A. Levi. 2012. Resistance to Phytophthora fruit rot of watermelon caused by Phytophthora capsici in US plant introductions. HortScience 47:1682-1689.

Kousik, C.S., M.L. Adams, W. Jester, R. Hassell, H. Harrison, and G. Holmes. 2011. Effect of cultural practices and fungicides on Phytophthora fruit rot of watermelon in the Carolinas. Crop Prot. 30:888-894.

Krasnow, C.S. and M.K. Hausbeck. 2015. Agerelated resistance of Cucurbita spp. fruit to Phytophthora capsici. Phytopathology 106: S1.5 (abstr.).

Krasnow, C.S., R.P. Naegele, and M.K. Hausbeck. 2014. Evaluation of fruit rot resistance in Cucurbita germplasm resistant to Phytophthora capsici crown rot. HortScience 49:285-288.

Lamour, K.H. and M.K. Hausbeck. 2000. Mefenoxam insensitivity and the sexual stage of
Phytophthora capsici in Michigan cucurbit fields. Phytopathology 90:396-400.

Lazarovits, G., R. Stossel, and E.W.B. Ward. 1981. Age-related-changes in specificity and glyceollin production in the hypocotyl reaction of soybeans to Phytophthora megasperma var. sojae. Phytopathology 71:94-97.

Loy, J.B. 2004. Morpho-physiological aspects of productivity and quality in squash and pumpkins (Cucurbita spp.). Crit. Rev. Plant Sci. 23:337-363.

McClure, T.T. and W.R. Robbins. 1942. Resistance of cucumber seedlings to damping-off as related to age, season of year, and level of nitrogen nutrition. Bot. Gaz. 103:684-697.

McGrath, M.T. 2000. Phytophthora fruit rot. APSnet Feature. 15 Mar. 2015. <http://www. apsnet.org/publications/apsnetfeatures/Pages/ PhytophthoraFruitRot.aspx $>$.

Mellano, H., D. Munnecke, and R. Endo. 1970. Relationship of seedling age to development of Pythium ultimum on roots of Antirrhinum majus. Phytopathology 60:935-942.

Meyer, M.D. and M.K. Hausbeck. 2012. Using cultural practices and cultivar resistance to manage Phytophthora crown rot on summer squash. HortScience 47:1080-1084.

Meyer, M.D. and M.K. Hausbeck. 2013a. Agerelated resistance to Phytophthora fruit rot in 'Dickenson Field' processing pumpkin and 'Golden Delicious' winter squash fruit. Plant Dis. 97:446-452.

Meyer, M.D. and M.K. Hausbeck. 2013b. Using soil-applied fungicides to manage Phytophthora crown and root rot on summer squash. Plant Dis. 97:107-112.

Newhall, A. and R. Wilkinson. 1949. Storage rots of squash in New York State. Plant Dis. Rep. 33:220-222.

Ppoyil, S.B.T. 2011. Effectiveness of mustard short-cycle cover crops for management of Phytophthora capsici and Fusarium spp. in cucurbits. MS Thesis. University of Illinois Urbana-Champaign, Champaign, IL.

Quesada-Ocampo, L.M. and M.K. Hausbeck. 2010. Resistance in tomato and wild relatives to crown and root rot caused by Phytophthora capsici. Phytopathology 100:619-627.

Schaffer, A.A. and C. Boyer. 1984. The influence of gene B on fruit development in Cucurbita pepo. J. Amer. Soc. Hort. Sci. 109:432-437.

Simonds, A.O. and W. Kreutzer. 1944. Infection phenomena in tomato-fruit rot caused by Phytophthora capsici. Phytopathology 34:813817.

Sutherland, P. and I. Hallett. 1993. Anatomy of fruit of buttercup squash (Cucurbita maxima D.) surface, cuticle, and epidermis. N. Z. J. Crop Hort. Sci. 21:67-72.

Waterhouse, G.M. 1963. Key to the species of Phytophthora de Bary. Mycol. Pap. 92:1-22. 